\title{
Kommentar
}

\section{Til skade og til gagn}

Ozon er en giftig gass som vi vet mye om fra eksperimentelle studier både på mennesker og dyr, men den kliniske erfaringen med helseskader er begrenset.

Artikkelen om akutte luftveissymptomer etter eksponering for ozon under arbeid på et vannbehandlingsanlegg er velkommen. I den beskrives helserisikoen for en yrkesgruppe som ikke er omtalt tidligere. To arbeidstakere fikk reaktivt luftveisdysfunksjonssyndrom (reactive airways dysfunction syndrome, RADS), som er en form for astma. Sykdommen var ikke var gått i full regress tre måneder etter siste eksponering.

Helseskadene etter ozoninhalasjon er i all hovedsak begrenset til luftveiene, men effekter på hjerte- og karsystemet i forbindelse med økt ozonkonsentrasjon i uteluften er rapportert (1). Det er ikke sikkert dokumentert om ozon kan gi kroniske luftveisskader etter lavgradig, men langvarig eksponering. Ved daglig moderat eksponering kan man opparbeide toleranse, slik at uendret eksponering gir mindre effekt etter om lag tre dager $(2,3)$. Adaptasjonen kan vare i omtrent en uke $(4,5)$. Ved moderat eksponering vil symptomene melde seg etter en til to timer $(6,7)$. I de aktuelle kasuistikkene kommer det frem at hodepinen meldte seg under arbeidet, mens luftveissymptomene først debuterte etter at arbeiderne kom ut i friluft. De hadde da vært $\mathrm{i}$ arbeid i omtrent fem timer. Kombinert eksponering med stoffer som $\mathrm{NO}_{2}$ og $\mathrm{SO}_{2}$ kan forsterke effekten av ozon. Det vil også økt pustefrekvens som følge av anstrengelse gjøre. Hvorfor luftveissymptomene først meldte seg etter endt eksponering, er ikke godt å si.

I arbeidslivssammenheng blir ozon brukt til bleking av papir og til desinfeksjon. Det brukes til desinfeksjon av drikkevann samt i stor utstrekning til desinfeksjon av sjøvann i fiskeindustrien. Doseringen er ikke alltid godt nok kontrollert. Det kan derfor oppstå slimhinneirriterende konsentrasjoner i inhalasjonsluften når ozonert vann blir fylt $i$ store kar i produksjonslokaler og brukt til spyling av gulvet. Så langt er det, etter det jeg kjenner til, ikke rapportert alvorligere symptomer fra fiskerinæringen, verken i Norge eller andre steder.

Ozon oppstår også under lysbuesveising og i xerografiske kopimaskiner, men jeg kjenner heller ikke til at det er rapportert helseskader i den forbindelse. Et mulig unntak kan være dødsfall hos sveisere på grunn av lungeødem. Dette er blitt tilskrevet eksponering for $\mathrm{NO}_{2}$, men det kan tenkes at ozon har bidratt. Det er vist at ozon kan gi økt permeabilitet i nedre luftveier (8), og i dyreforsøk kan det fremkalle lungeødem. For å motvirke ozoneffekten ved lysbuesveising med dekkgass, som brukes for å forhindre oksidasjon i sveisen, tilbys det gass som er tilsatt en liten mengde NO for å påskynde spaltingen av $\mathrm{O}_{3}$ til $\mathrm{O}_{2}$.

Myndighetene har så langt tillatt at ozongeneratorer blir markedsført som luftrensere og luktfjernere, i stor grad rettet mot helseog omsorgstjenesten. Kontroll med doseringen vil være ekstra påkrevd der, da mennesker med redusert lunge- og luftveisfunksjon er spesielt sårbare for eksponering. Såkalte luftrensere som fanger opp partikler gjennom ionisering, kan også danne små mengder ozon, men ikke mer enn at det kan regnes som harmløst.

Til bleking og desinfeksjon synes ozon å ha noen helsemessige fordeler fremfor alternative midler som klor og formaldehyd, men helseeffektene som kan oppstå, både ved uhell og etter lavgradig, men langvarig eksponering, er fortsatt mangelfullt dokumentert.
Håkon Lasse Leira

hakon.lasse.leira@stolav.no Arbeidsmedisinsk avdeling St. Olavs hospital

Håkon Lasse Leira (f. 1942) er overlege ved Arbeidsmedisinsk avdeling, St. Olavs hospital, og førsteamanuensis ved Norges teknisknaturvitenskapelige universitet.

Forfatter har fylt ut ICMJE-skjemaet og oppgir ingen interessekonflikter.

\section{Litteratur}

1. Hampel R, Breitner S, Zareba W et al. Immediate ozone effects on heart rate and repolarisation parameters in potentially susceptible individuals. Occup Environ Med 2012; 69: 428-36.

2. Frank R, Liu MC, Spannhake WE et al. Repetitive ozone exposures of young adults. Evidence of persistent small airway dysfunction. Am J Respir Crit Care Med 2001: 164: 1253-60.

3. Horvath SM, Gliner JA, Folinsbee LJ. Adaptation to ozone: duration of effect. Am Rev Respir Dis 1981 123: 496-9

4. Christian DL, Chen LL, Scannell CH et al. Ozoneinduced inflammation is attenuated with multiday exposure. Am J Respir Crit Care Med 1998: 158 $532-7$

5. Kulle TJ, Sauder LR, Kerr HD et al. Duration of pulmonary function adaptation to ozone in humans. Am Ind Hyg Assoc J 1982: 43: 832-7.

6. McDonnell WF, Horstman DH, Hazucha MJ et al. Pulmonary effects of ozone exposure during exercise: dose-response characteristics. J Appl Physiol 1983; 54: 1345-52.

7. Kulle TJ, Sauder LR, Hebel JR et al. Ozone response relationships in healthy nonsmokers. Am Rev Respir Dis 1985; 132: 36-41.

8. Koren HS, Devlin RB, Graham DE et al. Ozoneinduced inflammation in the lower airways of human subjects. Am Rev Respir Dis 1989: 139: 407-15.

Mottatt 11.5. 2012, første revisjon innsendt 31.5. 2012, godkjent 15.6. 2012. Medisinsk redaktør Kristin Viste. 